Article

\title{
Chromium Metal Biosorption Using Peanut Shell Adsorbent
}

\author{
Siti Annida ${ }^{1, a}$, Inayati ${ }^{1, b, *}$, Fera Setiawati ${ }^{1}$ \\ Chemical Engineering, Faculty of Engineering, Universitas Sebelas Maret, \\ Jl. Ir. Sutami Number 36A, Surakarta, Jawa Tengah 57126 \\ E-mail: annidasyifa3@gmail.com, binayati@staff.uns.ac.id
}

\begin{abstract}
One of the negative effects of the industrial growth is the presence of hazardous waste such as heavy metals. Chromium (VI) is a heavy metal which acts as the pollutant for the environment. Chromium concentration in water can be reduced using some methods. Adsorption is the most favorite method. Some of the biomass can be processed into adsorbent. This work was aimed to produce biosorbent from peanuts shell. The adsorbent was then used to adsorb chromium contented in water. Sodium hydroxide solution 0.5 M was used to activate peanut shell. Produced biosorbent was characterized using Fourier Transform Infrared Spectroscopy. The results showed that optimum condition for chromium adsorption was achieved at 30 minutes contact time with maximum adsorbed chromium of $0.022 \mathrm{mg} / \mathrm{g}$ adsorbent. The adsorption mechanism was in a good agreement with Langmuir isotherm.
\end{abstract}

Keywords: adsorbent, peanut shell, chromium, adsorption, isotherm.

EQUILIBRIUM Volume 2 No.1 January 2018

Online at http:// equilibrium.ft.uns.ac.id 


\section{Introduction}

The industrial revolution around the 18th century has encouraged a very large industrial development. Currently, increasing industries in a country have a positive impact in improving the quality of human life. However, on the other hand, industrial development rapidly will also have a negative impact if not offset by using advanced technology for handling waste generated. One of industry needs attention in waste management is the textile industry. Usually, synthetic dyes are used during the dyeing step of the textile production process. Synthetic dyes production is usually done through the addition of sulfuric acid or nitric acid which is often contaminated by arsenic or other heavy metals, such as chromium. Standard quality of wastewater for industrial effluent for total chromium, based on the regulation of Indonesian Ministry of Environment is not more than $1 \mathrm{mg} / \mathrm{L}$, thus the industrial effluent needs to be processed prior to discharging into the environment.

Some methods can be used for treating heavy metal waste i.e. coagulation, flocculation, precipitation, electrochemical, ion exchange, extraction, and adsorption. Adsorption method using adsorbent is the favourable method. Adsorption may be done using adsorbent made from biomass (a.k.a. biosorbent). One of biomass that can be processed into biosorbent is peanut shells. In Indonesia, peanut production can be reached 605,449 tons in 2015 [1]. Recently, peanut shells have not been utilized, thus peanut shells are still considered as waste.

Peanut shell contains water, ash, protein, cellulose, lignin, and fat. Cellulose in peanut shell is the largest content i.e. $\pm 63.5 \%[2]$. Cellulose is a linear chain-shaped glucose polymer which is connected by the $\beta-1,4$ glycosidic bond. The linear structure causes cellulose to be crystalline and insoluble. Cellulose is not easily degraded either chemically or mechanically. An active site which is contained cellulose can form a series of chemical reactions and bind with cationic and anionic compounds is hydroxyl bonds [3]. Peanut shell biosorbent has a potential ability to adsorb the hexavalent chromium ions in wastewater because of this bond. Hexavalent chromium $(\mathrm{Cr}(\mathrm{VI}))$ more harmful than trivalent chromium.

Many factors that influence the performance of the adsorbent i.e. metal concentration, surface area of the adsorbent, particle collision, $\mathrm{pH}$, and contact time. The surface area of the adsorbent can be increased by activation of the adsorbent. Activation can be done physically or chemically. However, chemical activation more economical from both activations. Activation can use acidic, alkaline, or halogen compounds.

Cellulose activation can be done by addition of alkali solution of $\mathrm{NaOH}, \mathrm{KOH}$, or $\mathrm{LiOH}$. It was revealed that $\mathrm{NaOH}$ is the best activator compared to $\mathrm{KOH}$ and $\mathrm{LiOH}$ [4]. The $\mathrm{NaOH}$ concentration which gives maximum adsorption capacity of phosphate ion adsorption process was $0.5 \mathrm{M}$ [5]. Therefore, it is important to know the maximum chromium metal adsorption capacity using the same activator agent. This study was produced peanut shell as biosorbent for chromium metal removal and to find the optimum contact time of the adsorption process.

\section{Theory}

\section{1 Adsorption}

Adsorption is the process which molecules fluid touch and concentrates at the solid surface [6]. Concentrated substance on the surface is defined as adsorbate and the material contains the accumulated adsorbate as the adsorbent [7]. Contact time is the most important factor in the adsorption process. Longer contact time allows the diffusion process and better adherence of the adsorbate molecule. The contact time to reach an equilibrium state in the metal adsorption process by adsorbents ranges from a few minutes to several hours [8].

The using of peanut shell as an adsorbent have been widely applied; for example: iod solution adsorption with the maximum adsorption capacity of $1269 \mathrm{mg} / \mathrm{g}$ adsorbent [9], methylene blue dye adsorption with optimum adsorption capacity of $400.06 \mathrm{mg} / \mathrm{g}$ adsorbent [10], and adsorption of phosphate ions with adsorption capacity of $10.4 \mathrm{mg} / \mathrm{g}$ adsorbent [5]. 


\section{2 Contact Time}

Contact time is the interaction time between adsorbent and adsorbate so that adsorption process reache optimum condition [11]. Contact time affects the adsorption capacity because due to the adsorption equilibrium state. The contact time may affect the attraction or interaction between adsorbent and adsorbate such as Van der Waals and electrostatic forces.

\section{3 Adsorption Isotherm}

Adsorbate concentration changing during the adsorption process according to the adsorption mechanism can be studied by determining its adsorption isotherm. There are two types of adsorption isotherms in this research, i.e., Langmuir and Freundlich isotherms. Langmuir isotherm is a monolayer approach which is the active surface of the adsorbent is only capable to adsorb one adsorbate molecule so that adsorption is limited to the formation of one layer. Freundlich isotherm, however, is multilayer approaches (many layers) in which the active surface adsorbent is capable of absorbing many adsorbate molecules [12].

To select the type of isotherm which able to describe the adsorption, an empirical equation, as written in equation (1) and (2) can be used to determine the adsorption capacity. Determination of isotherm depends on determinant coefficient (R2) [13].

Freundlich equation

Langmuir equation

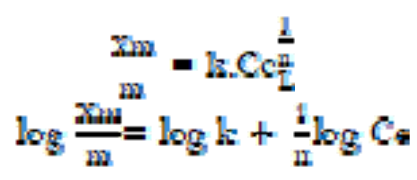

$$
\frac{m}{x_{m}}=\frac{1}{\mathrm{a} b} \cdot \frac{1}{\mathrm{c}}+\frac{1}{\mathrm{a}}
$$

\section{Method}

Materials are used in this study were peanut shells (Arachis hypogaea), sodium hydroxide solution, potassium dichromate solution, acetone, 1.5-diphenyl carbazide, deionized water, sulphuric acid solution, and phosphoric acid solution.

\subsection{Peanut Shell Adsorbent Activation and Preparation}

Peanut shell was cleaned and washed using clean water. The peanut shell was then dried under the sun for one day and then being ground to reduce their size into powder. Fifty grams of peanut shell powder was activated by soaking them in $\mathrm{NaOH}$ solution $0.5 \mathrm{M}$ for 24 hours. Activated peanut shell was then separated from the filtrate and then being dried in an oven at $80^{\circ} \mathrm{C}$ for 24 hours. The dried solid product was then ground and sieved to obtain the desired adsorbent particle size. FTIR analysis was conducted to characterize the adsorbent.

\subsection{Preparation of Standard Solution Curve}

The stock solution of $\mathrm{Cr}(\mathrm{VI})(1000 \mathrm{mg} / \mathrm{L})$ was prepared by dissolving potassium dichromate into aquadest. The solution was diluted into various concentration, i.e., $0.25 \mathrm{mg} / \mathrm{L} ; 0.5 \mathrm{mg} / \mathrm{L} ; 0.75 \mathrm{mg} / \mathrm{L} ; 1$ $\mathrm{mg} / \mathrm{L}$ and $1.25 \mathrm{mg} / \mathrm{L}$. The solution was added by acid solution and then added by 1.5-diphenyl carbazide solution. Absorbance was measured using UV-Vis spectrophotometer, at $540 \mathrm{~nm}$ wavelength hexavalent metal absorption. 


\subsection{Optimum Contact Time Determination}

Biosorption experiments were conducted using 0.2 grams of peanut shell powder that has been activated into erlenmeyer flask and $20 \mathrm{~mL}$ of potassium dichromate with a concentration of $1.25 \mathrm{mg} / \mathrm{L}$, then contacted for various contact time of $5,10,15,20,25,30,35,40,45,50,55$ and 60 minutes. To promote the better contact, the flask was shaken in constant speed of $250 \mathrm{rpm}$. After the adsorption process finish, the solution was filtered to remove the solid adsorbent. The filtrate was then analyzed by UV-Vis to analyze chromium concentration. The adsorption capacity was calculated using equation (4). Figure 1 is the experimental rig for chromium adsorption.

$$
\text { Adporption Capreity }=\frac{\left(C_{A,} C_{A,}\right)}{m} \mathrm{mV}
$$

1. Shaker

2. Erlenmeyer flask

Figure 1. Adsorption Equipment of Chromium Metals Using Peanut Shell Adsorbent

\subsection{Adsorption Isotherm Determination}

Determination of adsorption isotherm was done by measure the adsorption capacity with variation of chromium concentration: $0.25 \mathrm{mg} / \mathrm{L} ; 0.5 \mathrm{mg} / \mathrm{L} ; 0.75 \mathrm{mg} / \mathrm{L} ; 1 \mathrm{mg} / \mathrm{L}$ and $1.25 \mathrm{mg} / \mathrm{L}$. The sample was prepared by adding 0.2 grams of adsorbent into $20 \mathrm{~mL}$ chromium solution for each optimum contact time.

\section{Results and Discussion}

The study focusses on the chromium adsorption using activated peanut shell adsorbent with the varying contact time between the adsorbent and the adsorbate and determining the suitable adsorption isotherm.

\subsection{Characteristics of Peanut Shell Adsorbent}

The size of peanut shell adsorbents was $\pm 0.25 \mathrm{~mm}$. Adsorbents were characterized using FTIR. Figures 2 and 3 represent the peanut shell FTIR test results. Basic of FTIR interpretation can be seen in Table 1.

\begin{tabular}{|c|c|c|}
\hline \multirow{2}{*}{$\begin{array}{l}\text { Bond } \\
\text { Type }\end{array}$} & \multicolumn{2}{|c|}{ Absorption Region $\left(\mathrm{cm}^{-1}\right)$} \\
\hline & Calculated & Observed \\
\hline $\mathrm{C}-\mathrm{O}$ & 1113 & $1300-800$ \\
\hline $\mathrm{C}-\mathrm{C}$ & 1128 & $1300-800$ \\
\hline $\mathrm{C}-\mathrm{N}$ & 1135 & $1250-1000$ \\
\hline $\mathrm{C}=\mathrm{C}$ & 1657 & $1900-1500$ \\
\hline $\mathrm{C}=\mathrm{O}$ & 1731 & $1850-1600$ \\
\hline
\end{tabular}




\begin{tabular}{|c|c|c|}
\hline \multirow{2}{*}{$\begin{array}{l}\text { Bond } \\
\text { Type }\end{array}$} & \multicolumn{2}{|c|}{ Absorption Region $\left(\mathrm{cm}^{-1}\right)$} \\
\hline & Calculated & Observed \\
\hline $\mathrm{C} \equiv \mathrm{C}$ & 2101 & $2150-2100$ \\
\hline C-D & 2225 & $2250-2080$ \\
\hline C-H & 3032 & $3000-2850$ \\
\hline$-\mathrm{OH}$ & 3553 & $3800-2700$ \\
\hline
\end{tabular}

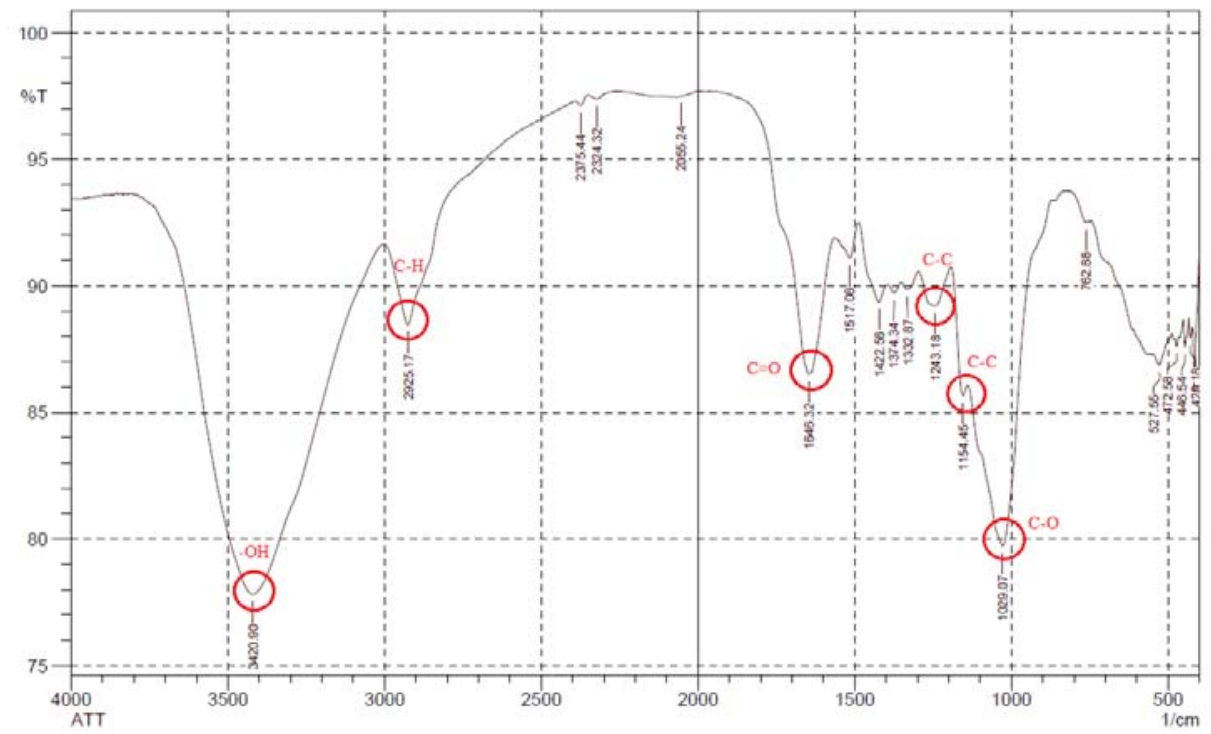

Figure 2. Peanut Shell Adsorbent FTIR Test Result before Activation

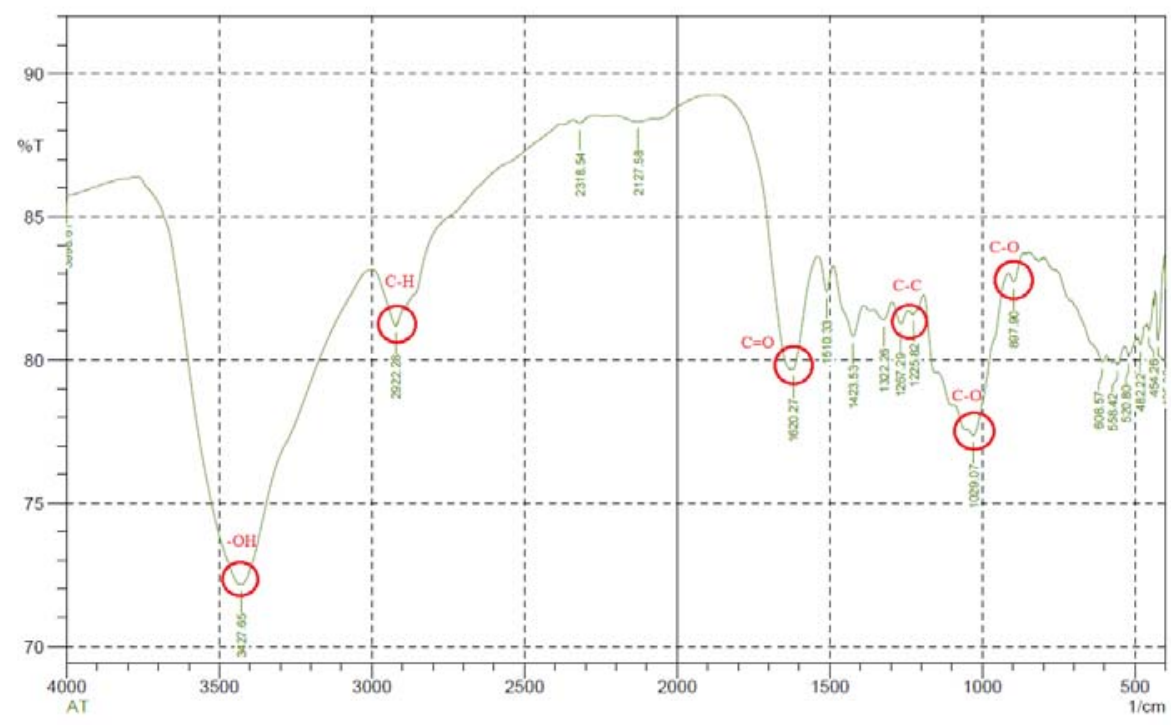

Figure 3. Peanut Shell Adsorbent FTIR Test Result after Activation

Based on Fig. 2 there is a peak of $1646.32 \mathrm{~cm}^{-1}$ for the $\mathrm{C}=\mathrm{O}$ bonds, in the peak $2925.17 \mathrm{~cm}^{-1}$ for the C-H bonds, two peaks of $1243.18 \mathrm{~cm}^{-1}, 1154.45 \mathrm{~cm}^{-1}$ for the C-C bonds, peak $1029.07 \mathrm{~cm}^{-1}$ for C-O bonds and peak $3420.90 \mathrm{~cm}^{-1}$ for -OH bonds. Based on Fig. 3 it can be said that there is a peak of $1620.27 \mathrm{~cm}^{-1}$ for the $\mathrm{C}=\mathrm{O}$ bonds, at peak $2922.28 \mathrm{~cm}-1$ for the $\mathrm{C}-\mathrm{H}$ bonds, two peaks $1267.29 \mathrm{~cm}^{-1}, 1225.82 \mathrm{~cm}^{-1}$ for the C-C bonds, two peaks $897.90 \mathrm{~cm}^{-1}, 1029.07 \mathrm{~cm}^{-1}$ for $\mathrm{CO}$ and peak bonds $3427.65 \mathrm{~cm}^{-1}$ for $-\mathrm{OH}$ bonds. Thus the FTIR test results indicate functional bonds according to the cellulose functional bonds on the peanut shell adsorbent. 
Table 2 shows the differences in the wavelength number of peanut shell adsorbent before activation and after activation. It indicates that there are differences in the quantity of adsorbent functional bonds. Correlation between the wave number of functional bonds with the mass and the quantity of the vibrating atom is inversely proportional. If the wave number decreases, the quantity of vibrating functional bonds increases, and vice versa. It's because of adsorbent activation process. Therefore, it can be said that the quantity of the peanut shell adsorbent functional bonds after activation more than the peanut shell adsorbent before it is activated.

Table 2 The Difference of Peanut Shell Adsorbent FTIR Spectrum

\begin{tabular}{|c|c|c|}
\hline \multicolumn{3}{|c|}{ Inactivated and Activated } \\
\hline \multirow{2}{*}{$\begin{array}{c}\text { Functional } \\
\text { Bond }\end{array}$} & \multicolumn{2}{|c|}{ Wave Number $\left(\mathrm{cm}^{-1}\right)$} \\
\hline & $\begin{array}{c}\text { Inactivated } \\
\text { Adsorbent }\end{array}$ & $\begin{array}{l}\text { Activated } \\
\text { Adsorbent }\end{array}$ \\
\hline $\mathrm{C}=\mathrm{O}$ & 1646.32 & 1620.27 \\
\hline $\mathrm{C}-\mathrm{H}$ & 2925.17 & 2922.28 \\
\hline $\mathrm{C}-\mathrm{C}$ & 1243.18 & 1267.29 \\
\hline $\mathrm{C}-\mathrm{O}$ & 1029.07 & 1029.07 \\
\hline$-\mathrm{OH}$ & 3420.90 & 3427.65 \\
\hline
\end{tabular}

\subsection{Standard Solution Curve}

The absorbance reading result of the standard solution shows maximum absorbance occurred at potassium dichromate solution concentration is $1.25 \mathrm{mg} / \mathrm{L}$. The standard solution curve is shown in Fig. 4.

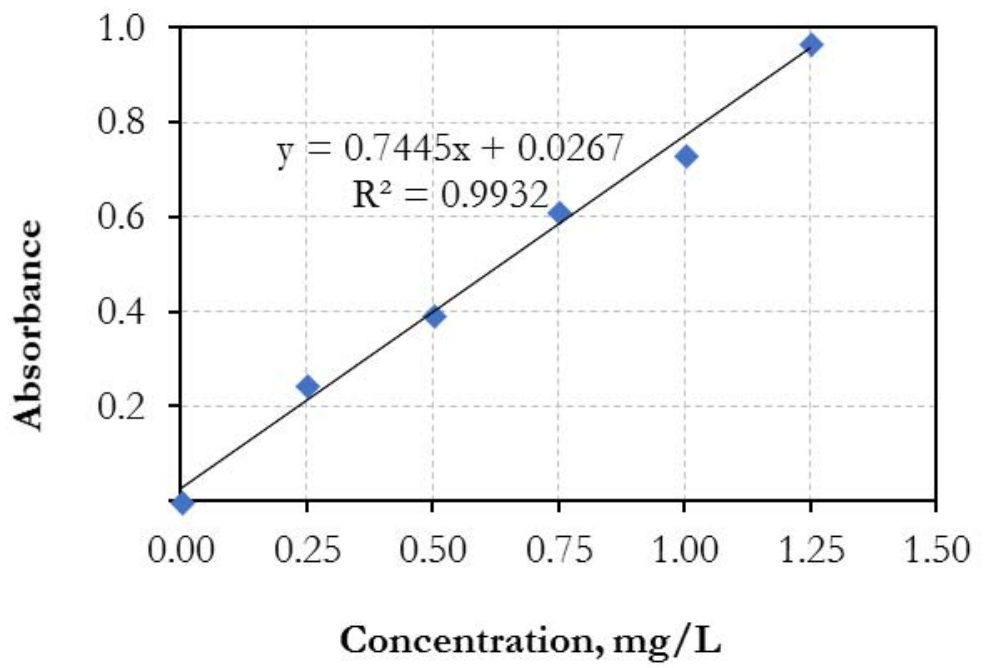

Figure 4. Standard Solution Calibration Curve

\subsection{Optimum Contact Time}

The chromium metal adsorption process using peanut shell adsorbents is an intertwined process of the adsorption-desorption equilibrium reaction. At the beginning of the reaction process, adsorption is more dominant than desorption so that the chromium adsorption process of the solution is going rapidly. It can be seen in Figure 5 that the process of adsorption speed increases up to 30 minutes. The optimum contact time occurs at the contact between the adsorbent and the chromium metal for 30 minutes with a maximum adsorption capacity of $0.022 \mathrm{mg} / \mathrm{g}$. After reaching optimum time, there is a very rapid adsorptiondesorption equilibrium and desorption velocity is faster than adsorption, so the total adsorption rate decreases. The adsorption process begins to decrease after optimum contact time up to 60 minutes. The desorption process occurs because the pore surface of the adsorbent is saturated so that it is unable to 
adsorb the chromium metal from the solution, even the chromium metal from the surface of the adsorbent is released again due to continuous shaking.

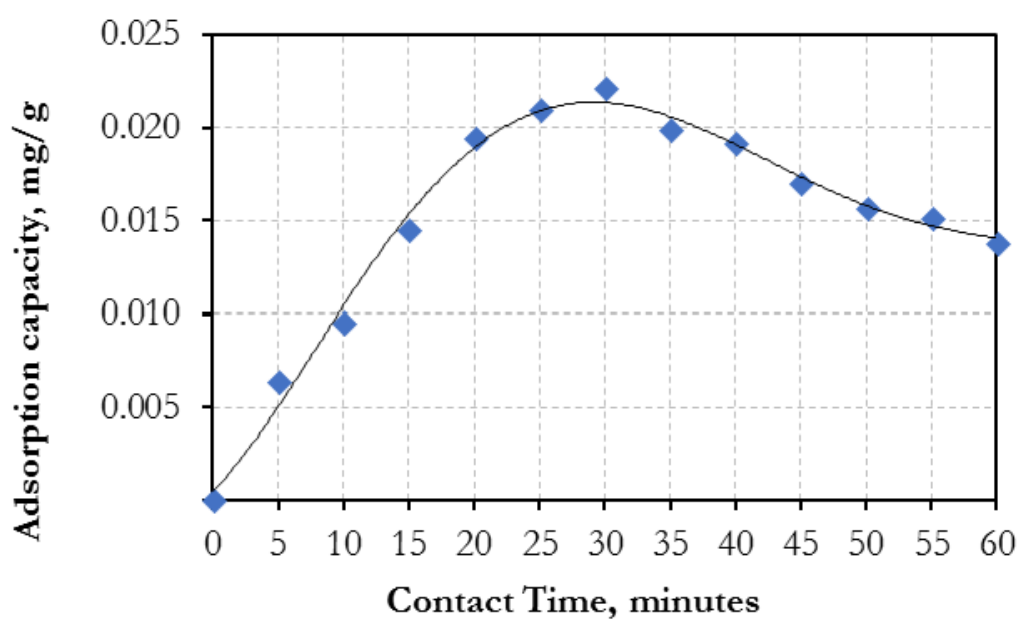

Figure 5. Effect of Contact Time on Chromium Metals Adsorption Capacity Using Peanut Shell Adsorbent

\subsection{Adsorption Isotherm Determination}

Isotherm adsorption is used to describe the adsorption process. Langmuir isotherm and Freundlich isotherm experimental results are shown in Fig. 6 and 7. Adsorption of $\mathrm{Cr}(\mathrm{VI})$ using peanut shells tends to follow the Langmuir isotherm. This is because the coefficient determinant $\left(\mathrm{R}^{2}\right)$ is higher, where the determinant value for Langmuir is 0.991 and Freundlich is 0.947 . Both isotherms equation constant can be seen in Table 3.

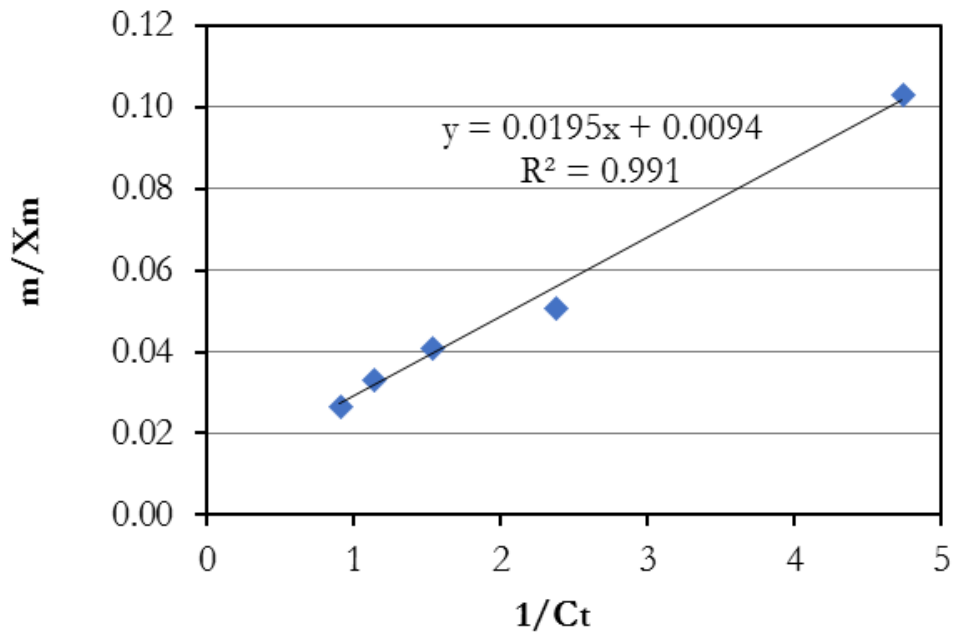

Figure 6. Graph of Correlation Between $(\mathrm{m} / \mathrm{Xm})$ and 1/Ct to Determine the Langmuir Equation Constants 


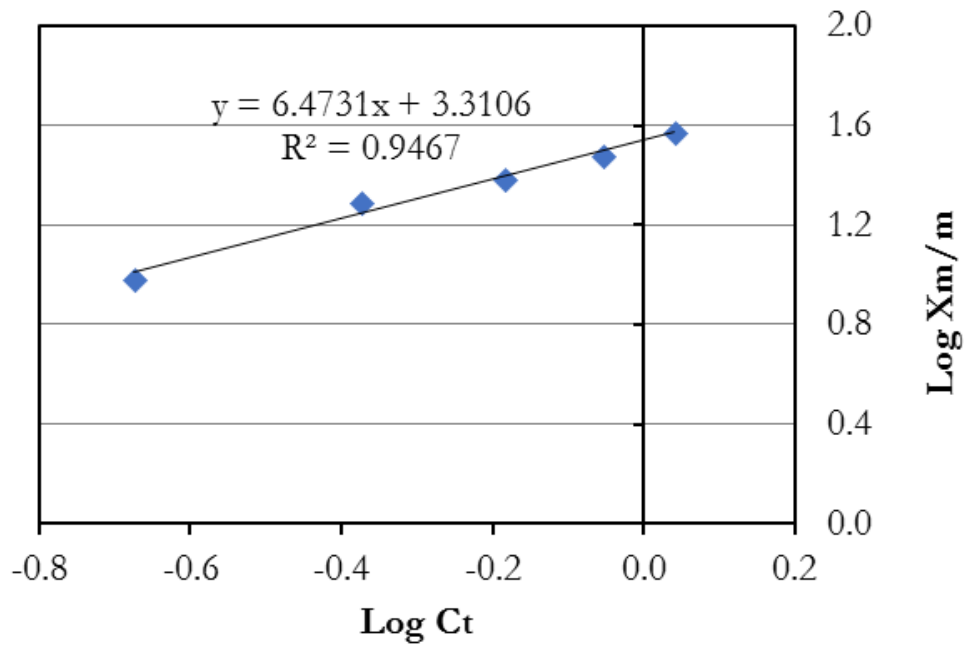

Figure 7. Graph of Correlation Between Log Xm/m and Log Ct to Determine Freundlich Equation Constants

Table 3. Langmuir and Freundlich Isotherm Test Results

\begin{tabular}{clrll}
\hline Isotherm & Constant & \multicolumn{1}{c}{ Value } & Isotherm Equation & \multicolumn{1}{c}{$\mathbf{R}^{2}$} \\
\hline Langmuir & $\mathrm{A}$ & 106.383 & $\frac{\mathrm{m}}{\mathrm{X}}=0.0195 \frac{1}{\mathrm{Ct}}+0.0094$ & 0.991 \\
& $\mathrm{~B}$ & 0.482 & $\mathrm{Xm}$ & \\
Freundlich & $\mathrm{K}$ & 2044.561 & $\log \frac{\mathrm{m}}{\mathrm{Xm}}=6.47 \log \mathrm{Ct}+3.3106$ & 0.947 \\
& $\mathrm{~N}$ & 0.155 & & \\
\hline
\end{tabular}

\section{Conclusion}

From the research that has been done can be concluded as follows:

1. The result of adsorbent FTIR testing from peanut shell with the size of $\pm 0.25 \mathrm{~mm}$ shows that the functional bonds suitable to the cellulose bonds from the peanut shell and increasing after activation.

2. The optimum contact time of the $\mathrm{Cr}(\mathrm{VI})$ adsorption process from the solution with the peanut shell adsorbent occurred at contact time of 30 min using an activated adsorbent by $0.5 \mathrm{M} \mathrm{NaOH}$ for $24 \mathrm{~h}$ with maximum adsorption capacity was $0.0222 \mathrm{mg} / \mathrm{g}$.

3. Langmuir isotherms (physisorption) is in a good agreement to describe the $\mathrm{Cr}(\mathrm{VI})$ adsorption process using the peanut shell adsorbent.

\section{References}

[1] Badan Pusat Statistik. (2015). Produksi Kacang Tanah Menurut Provinsi (Ton) Tabun 1993-2015. Available: http://www.bps.go.id. [Accessed: 4 April 2017]

[2] Departemen Pertanian. (2008). 'Kebijakan Teknis Program Pengembangan Usaha Agribisnis Perdesaan'. Departemen Pertanian. Jakarta.

[3] O' Connell, D. W., Birkinshaw, C.O., and Dwyer, T.F., "Heavy Metal Adsorbents Prepared from the Modification of Cellulose: A Review," Bioresource Technology, vol. 99, pp. 6709-6724, 2008.

[4] Fengel, D., and Wegener G., "Wood: Chemistry, Ultrastructure, Reactions," in Kayu: Kimia, Ultrastruktur, Reaksi-reaksi. Yogyakarta, Indonesia: Gadjah Mada University Press, 1995.

[5] Irdhawati I., Alling A., and Made A., "Daya Serap Kulit Kacang Tanah Teraktivasi Asam Basa dalam Menyerap Ion Fosfat secara Bath dengan Metode Bath," Journal Kimia Riset, vol. 1, no. 1, pp. 52-57, 2016. 
[6] Nasruddin., "Dynamic Modeling and Simulation of a Two-Bed Silicagel-Water Adsorption Chiller," Disertation, Rwth Aachen., Germany., 2005.

[7] Hines, A. L., and Robert N. M., "Mass Transfer Fundamental and Application". New Jersey: Prentice Hall Inc, 1985.

[8] Bernasconi, G., Gerster, H., Hauser, H., Stauble, H., and Schneiter, E., “Chemical Technology,” in Teknologi Kimia., 1st ed. Jakarta: PT. Pradaya Paramita, 1995.

[9] Saputro, M., "Pembuatan Karbon Aktif dari Kulit Kacang Tanah (Arachis hypogaea) dengan Aktivator Asam Sulfat," Final Task, Diponegoro University., Semarang., Indonesia, 2010.

[10] Hameed, B. H., and Foo K. Y., "Desalination and Water Treatment An Overview of Dye Removal via Activated Carbon Adsorptiom Process," Water Treat, pp. 37-41, 2012.

[11] Falahiyah., "Adsorpsi Methylene Blue Menggunakan Abu dari Sabut dan Tempurung Kelapa Teraktivasi Asam Sulfat," Final Task, Science and Technology Faculty., Universitas Islam Negeri Maulana Malik Ibrahim Malang., Malang., Indonesia, 2015.

[12] Amri, A., Supranto, and Fahrurozi M., "Kesetimbangan Adsorpsi Optional Campuran Biner Cd(II) dan Cr(III) dengan Zeolit Alam Terimpregnasi 2-merkaptohenzotiazol," Journal Nature Indonesia, vol. 6, pp. 111-117, 2004.

[13] Sembiring, Meilita Triana, and Sinaga., "Arang Aktif (Pengenalan dan Proses Pembuatannya)," Paper, Engineering Faculty., Sumatera Utara University., Sumatera Utara., Inonesia, 2003.

[14] Silverstein, M. R., "Identification of Organic Compound," 7th ed. United State of America, 1976. 